\title{
African Standby Force: A Song of Sorrow
}

\author{
Dr Ebere R Adigbuo \\ Senior Lecturer, Department of History and International Studies, PMB 1, Abraka \\ Delta State University, Abraka Nigeria
}

\begin{abstract}
Wars historically, have in no small measure, shaped human existence. Such issues like state formaton, boundary adjustments and consolidation, ethnicity, identity definitions and business relations have been influenced by wars. Africa disproportionately accounts up to forty percent of global conflicts. Although these conflicts have their devastating effects, they have nonetheless shaped the historical evolution of the continent. The methods adopted in resolving such conflicts are crucial to advancing knowledge about the continent. It is against this backdrop that the African Standby force is introduced. The need to establish an African military force was first advanced by the Nkrumah led Casablanca group, even before the birth of the Organization of African Unity in 1963. Though most of the African States that established the OAU that year rejected the idea of a continental military force, yet in 2002, the same states under the African Union (AU) voted for an African Standby Force for the purpose of a military intervention in the domestic affairs of member states in circumstances of genocide and war crimes. This study therefore undertakes to explain the rationale for the African Standby Force in implementing the AU's right of intervention and to appraise the prospects and challenges for the African Standby Force in implementing such right.
\end{abstract}

Keywords: African Standby Force, Conflict, War, Peace Mission, Intervention

\section{INTRODUCTION}

It is axiomatic that war and peace are central features of international relations. Over the years, states have been involved in series of conflicts and have at the same time enjoyed interludes of peace. Equally, the desire to bring an end to warfare and replace it with functional forms of interaction between states has been a major pursuit of nation-states including those in Africa. Post Cold War Africa is conflict ridden to say the least. Currently, many African countries are involved in war, or are experiencing post-war conflict and tension. Thus Africa projects the image of a continent where life is nasty, brutish and short in keeping with the Hobbessian state of nature. The persistence of violent conflicts in Africa has had a destructive impact on both human and material resources. In 1993 alone, 8 million Africans were refugees and about 40 million internally displaced due to internecine wars and conflicts (Olukosi 2002:3). In Rwanda, an estimated 800,000 people mostly minority Tutsis were exterminated in an ethnic cleansing between April and July 1994. In Burundi, about 150,000 people were slaughtered by Tutsi forces and insurgent Hutu militias between 1993 and 1997 (Sadiq 1993:29). Another major area of conflict in Central Africa is the Democratic Republic of the Congo. In West Africa, the major conflict afflicted countries include Cote d'Ivoire, Guinea, Liberia, Nigeria, Sierra Leone, and Togo. Conflicts in Africa post the Cold War had been widespread. In East Africa, the plagued countries are Eritrea, Ethiopia, Somalia, Sudan and Uganda. In North Africa, crises have reshaped Egypt, Libya, and Algeria; and in the Southern Africa, Angola and Zimbabwe are yet to know suitable peace. Of special significance in these wars ravaging Africa is the bitter war between Ethiopia and Eritrea that has spilled over into Somalia, where Eritrea has supported the jihadist group al Shabaab in its fight against the Ethiopian-backed government in Mogadishu. It is appropriate to mention the internecine wars between Sudan and South Sudan, where the forces have supported insurgencies in each other's backyards, and Sudanese Janjaweed militias have fought in eastern Chad and the Central African Republic (CAR). It is not as if these conflicts are new; what is new is that they have never been more linked than they are today. In most cases, terrorists' networks with criminal tendencies or hostile contiguous governments have empowered armed groups to seek control of these conflict ridden-African states. In 1998 as an example, Rwanda and Uganda's invasion kicked off what became known as "Africa's First World War" with nine neighboring states involved. Rwandan and Ugandan-backed insurgencies have plagued Eastern Congo (Prendergast, 2014). 


\section{Dr Ebere R Adigbuo}

It is sad to observe that from independence, Sub-Saharan African countries have witnessed over 80 successful and 108 failed coups (Barnes, 2005:3). Somalia has virtually descended into a state of lawlessness and anarchy with the end of the Cold War whilst Sierra Leone and Liberia were plunged into civil wars that unleashed untold horror and devastations on unarmed civilian populace. The situation in the DRC is the most pitiable, claiming over 5.4 million lives since 1996; making it the bloodiest since World War II (Hari, 2008). In addition, Rwanda as observed previously was engulfed in an unimaginable ethnic cleansing that led to the genocidal death of over 800,000 Rwandese, about the tenth of the population. These tales of armed conflict in post Cold War Africa have aptly been established by Thomas Ohlson in these words:

About one third of all armed intra-state conflicts between a government and rebel organization in the world during the period 1989-2007 occurred in Africa. Similarly, a total of 190 dyads of organized, intra-state armed violence - often coupled with violence against civilians - have occurred in 34 out of Africa's 53 states during the post-cold war period (1989-2007). So, one may ask: What is wrong with Africa? Why so many armed conflicts? (Ohlson, 2012:1)

At the base of these wars are the rich natural resources each of these poor African countries hold; these include diamonds, uranium, timber or oil. In many cases the problem is compounded by the foreign extractive multinational presence. The nefarious activities of the multinational companies remain opaque; instances abound when unreported payments to some African governments in return create and fund wars. In most cases, it has been discovered that these wars serve the purpose of creating a distraction, as these countries are robbed of their countries' natural resources. What is limply described as African wars and conflict is deliberately antagonized, so that the continent can be perennially blamed for its woes, while shielding the nefarious activities of the multinational companies. To this effect, a re-assessment of the efforts made by the African Union in its search for peace and security in the continent is worth the while; this task entails a reconsideration of the African Standby Force and how it has fared since its creation in the last fourteen years.

\section{AFrican Standby Force (ASF)}

The idea of an ASF is not new, since it had been a Pan-African ideal. In the sixties a lot of demands were made on the OAU for an African High Command. Though the idea did not work out, yet there were a variety of ad hoc measures in the field of conflict resolution. In 1981, the OAU created a shortterm all-African military force designed to resolve Chadian war. The African military force sought for about 4,800 troops which Nigeria, Senegal and former Zaire now called the Democratic Republic of Congo, gave their commitment (Schraeder, 2004: 258); the assignment failed as the continental load was left in the hands of Nigeria. The poor outing made the Nigerian President, Shehu Shagari, to complain of an unfair burden sharing since Nigeria bore the brunt of the expenses (Adigbuo 2013a). The OAU also deployed military personnel for peace support in Rwanda in 1993. The OAU's Neutral Military Observer Group (NMOG) was supposed to monitor the Demilitarized Zone between the then Government of Rwanda and the Rwanda Patriotic Front. Going by the Arusha Agreement, a measure of stability was maintained until the operation was handed over to the UN some months later. In May 1997, African leaders endorsed the need for a defence force that should comprise of existing military units of OAU member states. Though it was difficult to agree on the modalities of the force, yet there was the rudimentary understanding that the military units might be equipped with foreign assistance principally from the United States and France (Olonisakin, 2002:243).

The need for a joint defence force has since 1991 been cherished by many African states. The transformation of OAU to AU in 2002 and the adoption of the common defense and security policy in July 2004 were quite decisive. Re-echoing the need for joint defence, the Chairman of the AU in 2002/2003, South African President Thabo Mbeki, urged member states to appreciate the urgent need to establish an African Standby Force (ASF) to allow the continent to solve its conflicts. "Recent international events have confirmed the need for us Africans to do everything we can to rely on our own capacities to secure our continent's renaissance", Mbeki stated in 2003 prior to the annual meeting of Africa's foreign ministers in South Africa (Mbeki, 2003). The African Standby Force (ASF) when operational would have the following features:

- It is the African Union's multidisciplinary peacekeeping force

- It has the military, police and civilian contingents

International Journal of History and Cultural Studies (IJHCS) 
- The contingents are drawn from respective member-states of the AU

- The contingents must be ready for rapid deployment at appropriate notice.

In May 2003, the African Chiefs of Defence and Security (ACDS) adopted the "The policy framework document on the establishment of the African Standby Force (ASF) and of the Military Staff Committee" (African Union, 2003). The Council of African Foreign Affairs Ministers consolidated the proposal and the same was eventually endorsed by AU heads of state and government. By July 2004 the amended framework was adopted. Thus the ultimate adoption of the Security and Defence document has provided for the creation and development of the ASF as a military mechanism to deal with security crises on the continent (Cedric de Coning, 2004:4). The ASF operates under the direction of the African Union as specified in the policy framework. The overall aim of the African Standby Force is that Africa should possess the capability to act promptly, upon the request from a member state or when the African Union (AU) decides a situation is the type that can lead to grave crimes against humanity; the African Union's concern therefore is to save lives and prevent such conflicts from escalating. Invariably, it is in time of crisis that the ASF is meant to be deployed.

The ASF is established primarily to enable the African Union performs its interventionist role through its Peace and Security Council, particularly as it affects crimes against humanity. Emanating from the decision on the report of the fifth ordinary session of the Specialized Technical Committee on Defence, Security and Peace (peaceau.org 2011), Addis Ababa is the Headquarters of the Force, while the establishment of the ASF Continental Logistics Base (CLB) is located in Douala, Cameroon; Douala also houses the Technical Assessment Missions undertaken by the Commission. The ASF is established to carry out the following listed functions: (a) Observation and monitoring missions. (b) Any other peace support missions. (c) Military Intervention in a Member State in respect of grave circumstances or at the request of a Member State in order to restore peace and security, in accordance with Article 4(h) and (j) of the Constitutive Act of the African Union (CAAU). (d) Preventive deployment. (e) Peace building, including post-conflict disarmament and demobilization. (f) Humanitarian assistance to assuage the pains of civilian population in war torn areas; and (g) other functions authorized by the PSC or the AU Assembly.

The ASF undertakes to carry out these functions through the five regional standby brigade forces. These brigade forces include:

- The North Africa Regional Standby Brigade (NASBRIG),

- East Africa Standby Brigade (EASBRIG),

- Force Multinationale de l"eAfrique Centrale (FOMAC), for Central Africa;

- Southern Africa Standby Brigade (SADCBRIG) and

- An ECOWAS Standby Brigade (ECOBRIG) (Batware, 2011:3).

Following the recommendations of some military experts, the African Chiefs of Defense Staff met in Addis Ababa in May 2003, where they adopted the Policy Framework for the Establishment of the African Standby (Kent \& Malan, 2003:7). The Framework outlines six possible "conflict and mission scenarios" the ASF and by implication the African Union are likely to face and will need to respond to in the future (African Union, 2003):

\begin{tabular}{|c|}
\hline ASF Deployment Scenarios \\
\hline Scenario Description Deployment time frame \\
\hline Scenario 1: AU/regional military advice to a political mission 30 days \\
\hline Scenario 2: AU/regional observer mission co-deployed with a UN mission 30 days \\
\hline Scenario 3: Stand alone AU/regional observer mission 30 days \\
\hline $\begin{array}{l}\text { Scenario 4: AU/regional peacekeeping force for Chapter VI and preventive deployment missions (peace } \\
\text { building) } 30 \text { days }\end{array}$ \\
\hline $\begin{array}{l}\text { Scenario 5: AU peacekeeping force for complex multidimensional peacekeeping mission, including those } \\
\text { involving low-level spoilers } 90 \text { days, with the military component being able to deploy in } 30 \text { days }\end{array}$ \\
\hline
\end{tabular}

Source. The Policy Framework for the Establishment of the African Standby

Force and the Military Staff Committee Chapter 1 para. 1.6 
In 2004, the AU's looked forward to a force level of about 15,000-20000 soldiers since each of the five sub-regionally based brigades would contribute (3,000 to 4,000 troops) in addition to a sixth, continental, formation based at the AU's headquarters in Addis Ababa, Ethiopia. This will provide the AU with a combined stand-by capacity of 15,000 to 20,000 peacekeepers (Thorne, 2003:26).

The ASF Policy Framework called for the establishment of the force in primarily two phases.

\subsection{Phase 1. (Up To 30 June 2005)}

(1) AU Capability. The AU should develop and maintain the full time capacity to manage Scenario 1 and 2 (military advice to political mission and co-deployed observer) missions, and establish a standby reinforcement system to manage Scenario 3 (stand alone observer) missions. Experience suggests that at this level, a senior officer of the rank of Brigadier will be required in the PSD to provide an appropriate level of strategic military advice. The AU should also commence to develop a high readiness brigade capability (Cedric de Coning, 2003: 30-31).

(2) Regional Capability. Regions should within capacity develop their standby brigades within this phase. Where they can develop standby brigade groups, Regions should, by the end of this phase also develop the capacity to use a standby reinforcement system to manage Scenario 4 (AU/Regional PKF) missions. In addition to this preparation, by June 30, 2005, the AU also intends to enlist from 300 to 500 military observers and 240 police officers to be held in member states on 14 days' notice to move (Kent and Malan, 2003: 73).

\subsection{Phase 2. (1 July 2005 - 30 June 2010)}

The second phase of developing the ASF extends to June 30, 2010, during which the AU is supposed to have developed the capacity to manage a complex peacekeeping operation Just like the previous phase, sub-regions are expected to continue to develop the capacity to undertake a peacekeeping operation. Understandably, sub-regions that have managed to establish their standby brigades will be encouraged to enhance their rapid deployment capabilities. At this level, such regions will also be required to incorporate a small headquarters planning unit within the AU headquarters, as well as in each of the five sub-regions to plan and manage the size, mandate, and structure of a standby peacekeeping force (Kent and Malan, 2003: 74). In a nutshell, Phase 2 demands an AU Capability and a Regional capability as slated succinctly hereunder:

(1) AU Capability. In this period, while maintaining its full time capacity to manage Scenario 1 and 2, the AU should develop the capacity to manage up to Scenario 5 (complex Peace Keeping Force) missions. Experience suggests that at this level, a senior officer of the rank of Major General will be required in the Peace and Security Department (PSD) of Commission of the African Union to provide an appropriate level of strategic military advice.

(2) Regional Capability. All Regions should try to develop capabilities up to that of a standby brigade in this period, and those with existing brigades should increase their rapid deployment capability (Cillier, 2008:4).

Regrettably, Phase I that was to be implemented up until 30 June 2005 was delayed until 2010 and a new date was set for the achievement of the Full Operational Capability (FOC) of ASP to 2015. It is worrisome that the new deadline might go unrealized going by an assessment of the African Standby Force by an AU Panel of Experts in December 2013, which concluded that the ASF is unlikely to achieve full capability in 2015 without major efforts made by all stakeholders, particularly in the areas of doctrine, organization, equipment, training and capacities. Three ASF Roadmaps were developed to guide the operations of the ASF:

- Roadmap I (adopted in March 2005) spans from June 2006 to March 2008.

- Roadmap II (adopted in April 2004) spans from April 2008 to December 2010.

- Roadmap III (adopted in December 2010) covers from December 2010 to December 2015.

The implementation of the concept of the African Stand-By Forces based on regional brigades was supposed to take effect from in 2015 (Cilliers 2008: 2).

At the end of Phase II, in 2010, the African Standby Force was supposed to be operationally ready for deployment, including its complex peacekeeping operations and military intervention as defined in Article 4(h) of the Constitutive Act. In effect, the AU with the regional economic communities 
(RECs)/regional mechanisms (RMs) should have technically developed all policy documents and technical concepts and institutional structures, prepared the pledged units for deployment through training and joint exercises and should have had a reasonable level of, if not all the required, infrastructural capability (Cilliers 2008: 2-5).

The ASF Roadmap III acknowledged that the set goals in Phase One were not achieved until 2010; a new date was therefore set for the realization of the Full Operational Capability (FOC) to 2015.

\section{ASF: Fourteen Years After Creation}

2003 is a historic year as it marks the birth of the African Standby Force (ASF) project. Over the last 14 years, some modicum of progress has been made by the AU in assembling its troops in 2015 for the first time for training at the South Africa's Army Combat Training Centre in Lohatla; it has also committed about 22000 of its peacekeeping troops in Somalia. The AU has shown its preparedness to respond in her other areas of conflict like Mali and South Sudan. Some analysts have therefore paid glowing tribute to the $\mathrm{AU}$ for conceiving the idea of self-dependence in its security matters. Nonetheless, as it concerns progress towards making the ASF operational, the record is nothing to write home about, at least judging from the postponement of the target date for the force from 2010 to 2015. Equally, intra-state tensions and significant imbalances regarding the development of different components or within the African regional organizations are clear challenges confronting the African Standby Force. These very important factors are noticeable in all the regional economic communities (RECs). Likewise many of the RECs Brigade Headquarters are poorly staffed (Fisher, 2010). Other structural weaknesses as outlined hereafter pose further challenges to the operations of ASF.

\section{WEAK LEGAL FRAMEWORK}

In managing conflicts in Africa, it is necessary that the AU is equipped with an appropriate legal authority. As a matter of fact, to guarantee a legitimate deployment of the African Standby Force in any conflict situation, the AU must be endowed with the legally established mandating authority. The ASF can be deployed in two instances, going by Article 13 of the PSC Protocol: the peace support missions and military intervention under Article 4(h) of the Constitutive Act. Only a minute legal thin line differentiates the two situations. Peace operations, as shown in Scenarios 1 to 5 do not involve actual use of force; whereas military interventions apply only in grave circumstances involving war crimes and other crimes against humanity as roofed by ASF mission Scenario 6. In general, peace support missions unlike military interventions can only take place with the support and consent of the host country. Peace missions as stipulated in the UN Charter involves the maintenance or restoration of international peace and security; the grounds for intervention by the ASF as captured under Scenario 6 are what the Constitutive Act called grave circumstances namely war crimes, genocide and crimes against humanity. The aim of such intervention is quite specific: to prevent or stop the perpetration of gross war crimes as different from the normal maintenance of global peace and security as implied within the framework of the UN Charter (Dersso, 2009). The AU needs a legal authority for deployment of both peace support operations and outright military intervention. Besides these legal lapses confronting the $\mathrm{AU}$ in its self assigned interventionist force, some regional communities are operating a weak legal framework, while others have no binding legal framework or have not signed any memorandum of understanding (MOU). An example is the East African Standby Force that is working with only an MOU and a Policy Framework that are not binding to the East African states. Even at this, there is no binding arrangement between member states for force deployment, even though on yearly basis the states renew their troops pledged. Poor staffing as observed earlier, is quite prominent in the East African Standby Force with only three members of staff as at 2010.

\section{FinANCIAL DEPENDENCE}

The African Union relies on funds from the European Union, the United States and other African states. Virtually in any operation, the AU has been faced with lots of financial constraints. In the Sudan operations as an example, the African Mission in Sudan (AMIS) was estimated to initially cost $\$ 158$ million out of which $\$ 63$ million was to be provided directly by member states, while the balance of $\$ 95$ million was to be raised voluntarily. AU could not meet the initial target. As regards the Burundi Mission, out of a budget of $\$ 121$ million to support 2,300 contingents deployed in that country, only $\$ 10$ million was raised leaving the troop contributing states to bear the burden (Sesay, 2013:416). At the regional level, the moment the Standby Brigades gave teeth to the noble intention 
they won considerable western support. The US provided $\$ 500 \mathrm{~m}$ to train up to 50,000 African troops. The British also doled a substantial amount, committing more than $£ 110 \mathrm{~m}$ a year via the African Conflict Prevention Pool for nearly a decade. As at 2014, the figure stood at $£ 51.5 \mathrm{~m}$. From all indications the African Standby Force is financially dependent on foreign donors and it is a source of worry as it invalidates the claim of an African solution to African problems, due to its high dependency on external support.

\section{Logistic Problems}

In reality, the Standby Brigades have not got off the ground. Differences between African states deeply affect the determination for a joint military force. Many African troops from member states are insufficiently trained, armed or disciplined to be deployed effectively. In November 2013 the South African government announced that its force would be renamed in the face of these lapses. Some analysts wonder the credibility of the ASF since the Standby Brigades had made little progress since they were conceived more than thirteen years ago. It is not easy to understand the reasons behind the abysmal sluggishness of the African Standby Force. Does it mean that Africa is incapable of running military operations, without logistical support from outside? Surprisingly that is the state of affairs and in cases of military intervention as in the situation in Somalia, the deployment of the Ethiopian army remains subordinated to the Ethiopian political power; in effect, the Standby institutions are merely instruments to pursue national interests and military capacity building; it mitigates the lack of reactivity of a regional structure. The atrocities in Rwanda could have been prevented seemingly had the ASF been deployed within two weeks as mandated by the Peace and Security Council (PSC) of the AU (Cilliers, 2008: 9). In practice, Africa lacks a strategic airlift capability needed in rapid military deployments. This accounts for the AU dilemma in deploying troops to Sudan's troubled Darfur region. Months after the PSC mandated the deployment of troops in 2007, Rwandan and Nigerian troops waited in their respective countries whilst the conflict in Darfur claimed more lives. The United States Air Force later came to Africa's rescue. The North Atlantic Treaty Organization (NATO) equally assisted in equipping the African peacekeepers. It is against this backdrop that the ASF remains a song of sorrow unless it is adequately resourced

\section{Communication Problems}

Africa is not a unitary nation from all indications; this is quite glaring particularly in its diversity of languages. The continent boasts over 2,000 or more languages. Military commanders naturally find some difficulty communicating with their counterparts from other African states and even with their own troops, as many individual African nations have numerous languages spoken within their borders. Nigeria, for example, has over 510 linguistic groupings (Gordon, 2005). There are inherent difficulties in attempting to create a cohesive force from widely disparate populations. Should a nation's military choose only soldiers who speak the same language; numerous others will be disenfranchised, which can lead to internal dissent. On the other hand, it can be costly in both money and time to train and fully integrate a military force of different linguistic backgrounds (Feldman, 2008). Language thus serves as both a barrier to communication among the nations who volunteer for peacekeeping missions, as well as to soldiers from various ethnic groups within each nation. Unlike NATO, where English and French are the official languages and where many troops are bilingual, it would be difficult, for political and economic reasons, to create a large African Union force composed of several countries where large numbers of soldiers speak one of only two official languages (Feldman, 2008). The language problem is compounded by illiteracy that is notoriously high in many African nations. Some soldiers will find it difficult or impossible to understand manuals and written orders. Besides language, culture also comes into play when trying to forge a coalition of forces from different African nations. Religion, values, and traditions can all create numerous obstacles. These problems can range from supplying acceptable food to dealing with religions forbidding women to serve in the ranks (Feldman, 2008).

\section{National Interests/Dual Centre of Authority}

There is a need to ensure political consensus among nations before an operation can be approved and deployed. The AU's Peace and Security Council is a political body composed of member states that pursue diverse national interests. Its decisions regarding the deployment of an ASF Mission will therefore depend, among other things, on the interests and political dynamics of members of the PSC and the strength and diplomatic skills of the Chairperson of the PSC in any given crisis situation. 
Forging a consensus amongst PSC members will be critical to the speediness and legitimacy of its decisions and, therefore, also of the deployments themselves. There are other operational problems. There are lots of structural weaknesses in the composition of the ASF. The composition is suggestive that there are at least two entities having authority over the use and deployment of intervention forces: the PSC/AU on one side and the regional economic communities on the other. There is therefore the possibility of collision on the role and authority of these bodies. There is also a lack of clarity whether the AU, PSC and the AU Commission need to deal directly with member states in which the contingents composing the regional brigades or whether they have to correspond and liaise with Regional Economic Communities.

\section{Conclusion}

The creation of an African Standby Force was a positive development for Africa; the establishment of the ASF was truly ground-breaking in that it operationalized the interventionist humanitarian norm of the African Union. Despite problems that range from sourcing funds, developing common command and control, improving communications, overlapping memberships of the regional brigades and the danger of one state dominating the regional brigade, military officers across nations and regions have demonstrated tremendous leadership in moving the concept of the ASF from the drawing board and into military academies and onto the battlefield. Unfortunately, the greatest challenges are political, not military, as to the success of the ASF. Irrespective of the great military strides undertaken, the underlying political values of Africa's political leadership prevent the effective deployment of such a force. For this reason, conflict and wars will continue to be a recurring feature of Africa's political landscape. The poor will remain with us as the African Standby Force is likely to go the way of so many other initiatives. From all indications, the African Standby Force remains a song of sorrow.

\section{REFERENCES}

[1] Adigbuo, E.R. (2013a pp 11-21). "Diplomatic and Military Co-operations in Nigeria's Foreign Policy". International Affairs and Global Strategy, Vol 13.

[2] Adigbuo, E.R. (2013b pp 30-57). "Nigeria's Sovereignty, Niger Delta and Imperatives of State Reconstruction". The Constitution. Vol 13, No. 3, September.

[3] African Union (AU) (2013). Encyclopedia Britannica http://www.britannica.com/EBchecked/ topic/8408/African-Union-AU accessed 6/10/14.

[4] African Union Independent Panel of Experts (October 2013): Assessment of the African Standby Force and Plan of Action for Achieving Full Operational Capability by 2015.

[5] AU Peace and Security Council (2007). Communique of the 69th Meeting of the Peace and Security Council, PSC/PR/Comm (LXIX), 19 January. Addis Ababa: African Union.

[6] African Union (2014) "Meeting of African Ministers of Defense, Safety and Security, Addis Ababa, Ethiopia" http://www.au.int/en/content/meeting-african-ministers-defense-safety-andsecurity-addis-ababa-ethiopia accessed 07/10/14.

[7] African Union, Policy Framework for the Establishment of the African Standby Force and Military Staff Committee, adopted by the African Chiefs of Defense Staff (Addis Ababa: Ethiopia, May 15-16, 2003).

[8] African Union. 2004. Policy Framework for the Establishment of the African Standby Force and the Military Staff Committee. Assembly of the African Union, Third Ordinary Session, Addis Ababa, Ethiopia, 6-8 July.

[9] AMISON (2007). "African Union Mission in Somalia” http://amisom-au.org/amisom-back gro und, accessed 14/10/2014.

[10] AMISON (2011). "AU, TCC, international partners meeting on Somalia). http://amisomau.org/2011/09/au-tcc-international-partners-meeting-on-somalia, accessed 14/10/14.

[11] Barnes, S. T. (2005, April). "Global Flows: Terror, Oil, and Strategic Philanthropy," Asian Stu dies Review, Vol. 48, Issue 1.

[12] Batware, B. (2011). "The African Standby Force A Solution to African Conflicts"? http://acuns. org/wp-content/uploads/2012/06/AfricanStandbyForce.pdf accessed 6/10/14.

[13] Cedric de Coning, (2004). "Towards a Common Southern Africa Peacekeeping System", CIPS Electronic Briefing Paper 16, 4. 
[14] Cedric de Coning, (2003). "Peacekeeping Trends", Conflict Trends 4, pp 30-31.

[15] Cilliers, J. (2008) 'The African Standby Force: An update on Progress', ISS Paper 160, March 2008, Pretoria: Institute for Security Studies.

[16] Feldman, R.L. (2008). Problems Plaguing the African Union Peacekeeping Forces Defense \& Security Analysis Vol.24, No.3, pp. 267-279, September.

[17] Fisher, L. M. et.el (2010). Moving Africa Forward "African Peace and Security Architecture (APSA) 2010 Assessment Study".

[18] Gberie, L. (August 2013). "Intervention brigade: End game in the Congo"? UN peacekeeping task enters a new phase Africa-Renewal http://www.un.org/africarenewal/magazine/august2013/intervention-brigade-end-game-congo. Accessed 21/10/14.

[19] Gordon, R. Jr (ed.), (2005). "Languages of Nigeria", Ethnologue, 2005, http://www.ethno- logue. com/show_country.asp?name=Nigeria, accessed 9 October 2014.

[20] Hari, J. (2008 October 30). "How We Fuel Africa's Bloodiest War." The Independent, http:// www.independent.co.uk/voices/commentators/johann-hari/johann-hari-how-we-fuel-africasbloodiest-war-978461.html accessed on 22/09/2014.

[21] Human Rights Watch (2014) "SOMALIA: HRW Statement regarding its recent report on Sexual Exploitation and Abuse by AMISOM Peacekeepers" http://www.hrw.org/news/2014/09/25/ statement-regarding-recent-report-sexual-exploitation-and-abuse-amisom-peacekeepers.

[22] International Commission on Intervention and State Sovereignty, 'The Responsibility to Protect' (2001, December) http://responsibilitytoprotect.org/ICISS\%20Report.pdf accessed 4 September 2014.

[23] Kent V and M Malan, (2003) "The African Standby Force: Progress and Prospects", African Security Review 12/3.

[24] Leijenaar, A. (2013). "Peacekeeping: changing horizons and new realities", ISS Pretoria 14 March.

[25] Mbeki, T. (2003). "Mbeki Wants Standby Force Prioritized", Business Day (May 23). www.bday.co.za/bday/content/direct/1\%2C3523\%2C1352396-6098-0\%2C00.htm).

[26] Nhema, A. G. (2004, pp 1-21). "Introduction", in Alfred G. Nhema (ed), The Quest for Peace in Africa: Transformations, Democracy and Public Policy, Addis Ababa: International Books with OSSERA.

[27] Ohlson, T. (2012). From Intra-State War to Durable Peace: Conflicts and its Resolution in Africa after the Cold War. Republic of Letters Publishing.

[28] Olukoshi, A (2002). "Governing the African Development Process: the Challenges of the New Parnership for Africa's Development (NEPAD)", public lecture delivered at NIIA, July 9, 2002.

[29] Olonisakin, F. (2002). "Conflict and Conflict Resolution", in McGowan, P. and P, Nel, (eds). Power, Wealth and Global Equity: An International Relations Textbook for Africa. UCT Press: Cape Town.

[30] Peace and Security Council report No.2, September 2009 http://www.issafrica.org/uploads/ NO2SEP09.PDF.

[31] Prendergast, J. (2014). "The New Face of African Conflict, In Search of a Way Forward", Foreign Affairs, March 12.

[32] Report of the $5^{\text {th }}$ Ordinary Session of the Specialized Technical Committee on Defence, Security and Safety Addis Ababa, Ethiopia, 23-26 October 2011 http://www.peaceau.org/uploads/ex-cl698-xx-e.pdf accessed 5/10/14.

[33] Para 1.6 of the Policy Framework for the Establishment of the African Standby Force and the Military Staff Committee (Part I): adopted by the Third Meeting of African Chiefs of Defense Staff, 15 - 16 May 2003, Addis Ababa.

[34] Sadiq R (1993) “Africa at the Doorstep of the $21^{\text {st }}$ Century: Can Crisis Turn to Opportunity?" in Adebayo Adedeji (ed): Africa within the World: Beyond Dispossession and Dependency, London: Zed Books.

[35] Schraeder, P (2004). African Politics and Society: A Mosaic in Transformation, 2nd edition (Wadsworth: Belmont). 
[36] Sesay, A. (2013). "From the OAU in Chad to the AU in Darfur: the Limits of Peace Keeping by Africa's Regional Organizations" in Akinterinwa B. A. (ed.) Organization of African Unity/ African Union at 50. NIIA: Lagos

[37] Solomon H (2012). "Critical Reflections of the African Standby Force: The Case of its SADC Contingent" Southern African Peace and Security Studies Vol 1 No.2 pp 20-28.

[38] Thorne, E A. (2003). "The African Standby Force Takes Shape: An Observation of Needs and Necessary Actions", African Armed Forces Journal (July) p. 26.

[39] UN-Resolution 2085 (2012).http://www.un.org/News/Press/docs/2012/sc10870.doc.htm accessed 20 October. 